\title{
Emergence and Development of Contemporary Neoliberalism
}

\author{
Juntao Ding ${ }^{1}$, Dingyu Yang ${ }^{2, *}$ \\ ${ }^{1 .}$ School of Marxism, Hubei University of Economics, Wuhan, 430205, China.Email: 474754862@qq.com \\ 2.Hillfield Strathallan College, Hamilton, ON L9C1G3, Canada.Email: 942228801@qq.com \\ *Corresponding author.Email:942228801@qq.com
}

\begin{abstract}
Neoliberalism is an economic theoretical system of contemporary western economic theory which lays great emphasis on libertarianism theory, and was formed during the 1920s-1930s. After the 1970s, its theory was widely promoted and practiced, which brought remarkable influence to the development of world politics and economy. As a result, neoliberalism became an important theoretical school in the economic theoretical system. This academic school attracts the attention of many economists in the world, some economists criticize it while others praise. Thus, neoliberalism has become a focus and the core of controversy. Consequently, in the contemporary Internet finance and digital economy environment, the arrangement of its development sequence plays a fundamental role by analyzing its advantages and disadvantages.
\end{abstract}

Keywords: Neoliberalism, capitalism, globalization.

\section{HISTORICAL BACKGROUND OF EMERGENCE OF CONTEMPORARY WESTERN NEOLIBERALISM}

Neoliberalism is an economic school developed after the 1930s. In the 1930s, an economic crisis had an impact on the whole world, and also completely exposed the disadvantages of the libertarianism market economy. This crisis didn't only mean the total negation of the classical liberalism economic theory, but also declared the end of the era of free competition capitalism. Since then, Keynesianism occupied the mainstream position and became the mainstream economics of capitalist society. For a period after that, the views of neoliberalism scholars were not given great attention. So that they adjusted and systematized their theory to adapt to the requirements of the times. Many important works of neoliberalism were written at this stage. In general, neoliberalism still adhered to the principle of liberalism, and its theoretical source was still classical economic liberalism since Smith with a certain changes. Namely, it became further microcosmical and mathematical on the analysis method and simultaneously introduced the economic theory into various aspects of the social life.

During the 1950s-1960s, the argument between neoliberalism scholars and Keynesianism scholars became increasingly fierce. They began to criticize the interventionist school of western countries, and even blamed the economic system of socialist countries. In 1944, Hayek, a Nobel Laureate, published The Road to Serfdom. In this article, he pointed that "the private ownership is the most important guarantee of freedom, not only for the property owners, but also for the proletarians. It is only because the means of production are held by the people who act independently that no one has full control over us, and then we can decide what we should do as a private person."[1] Hayek attacked all restrictions from the state to the free operation of the market. And he thought that the control and intervention of the state had seriously damaged economic freedom and political freedom. However, people didn't pay much attention on Hayek's proposition for a long time. Up to now, neoliberalism not only includes Hayek's neoliberalism theory, Friedman's monetarism theory and West Germany's social market economy theory, but also forms a huge group which consists of human capital theory, public choice school, neo-institutional economics school (property rights economics, etc.), supply-side school and neoclassical macroeconomic school (once known as rational expectation school). The representatives of neoliberalism school, Hayek and Friedman; representative of the human capital theory, Theodore Schultz; representative of public choice school, James Buchanan; representative of property rights 
economics, Ronald Coase; and representative of rational expectation school, Robert Lucas, have once won the Nobel Memorial Prize in Economic Sciences. Neoliberalism has made remarkable achievements in the academic circles and been widely recognized.

Since the 1960s, especially after the oil crisis in 1973, a major crisis occurred to the post-war world economy. Many capitalist countries had been impacted by such crisis with a situation of low growth and high inflation. The mentioned situation was a serious challenge to Keynesianism. During this period, the Western neoliberalism theory attracted people's attention, developed vigorously and entered a period of great prosperity which is rare for itself. The influence it obtained in the world economy was no less than that of Keynesianism. Especially in the period of Keynesianism failure in the 1960s as well as the period of economic reform in socialist countries since the 1980s. Neoliberalism made a breakthrough development in the two above-mentioned periods, and gradually became a mainstream school of world economics.

In the late 1960s, the western capitalist countries entered a period of low growth after experiencing the post-war recovery, which was a major change in the postwar western economy. The Keynesianism involving in the theory of employment and inflation was difficult to adapt to the actual development at that time. This theory began to be in a dilemma and was questioned by more and more people. Moreover, neoliberalism got more and more support and began to become an international economic ideological trend. This ideological trend contains many scholars' arguments with the basic beliefs of that "the free market mechanism can automatically realize the optimal allocation of resources as well as the full employment equilibrium" and "oppose state intervention and stand for libertarianism", etc.

After neoliberalism was recognized and practiced in some countries, great achievements were made, especially in the Reagan Administration of the USA and the Thatcher Administration of the UK, which made the economy solve a dilemma and get a better growth again. In 1979, Mrs. Margaret Thatcher took up the post of British Prime Minister. The Thatcher Government was the first government among developed capitalist countries to publicly declare the practice of neoliberalism. The USA, Germany and other countries began to implement neoliberalism policies soon after that. In the UK, the Thatcher Government began to control the total money supply, increase interest rates accordingly, reduce income tax by a large margin, cancel all kinds of control, and cut social expenditure. Western developed capitalist countries have more or less implemented the corresponding policies and achieved remarkable results.

\section{BASIC THEORY AND POLICY PROPOSAL OF NEOLIBERALISM}

The internal western liberalism possesses many factions. The principles and theories they believe have a certain similarity to each other, which can be divided into three classes: 1. Extreme Neoliberalism. It believes that the economy should fully return to a state of libertarianism, and holds a complete negative attitude towards government intervention. 2. Moderate Neoliberalism. It believes that the society should be combined with market, and make government intervention and free competition cooperate with each other. 3. Innovative Neoliberalism. It is the most popular liberal school since the $1980 \mathrm{~s}$. Its principle of libertarianism is quite different from the previous principle, and adds new contents. There are some commonalities in the ideas and propositions of neoliberalists, which mainly embody in: 1 . It believes in the spontaneous regulation of the market mechanism and believes that the capitalist market economy is perfect, and the rational allocation of resources can be realized by the power of the market; 2 . It believes in the superiority of the private enterprise system and advocates providing the private economy with full freedom. It believes that the private system is the prerequisite of competition, and can also give full play to individual positivity; 3 . It opposes government intervention in economic activity. It thinks that the state intervention will distort the market and make the market fail to convey accurate information; 4 . It opposes monopoly, support market competition, and it believes that the monopoly will hinder market mechanism from playing its role; 5 . It adheres to sound fiscal policies and opposes the welfare state system. It believes that the welfare state system is not conducive to market competition and weakens the motive force of economic development.

Although there are many commonalities in neoliberalism, they still have a certain difference as well as different theoretical schools inside.

First, monetary school, and its representative is Milton Friedman. It opposes state intervention in the economy, and it thinks that the spontaneous force of the market can make the economy tend to be balanced, and it highly praises libertarianism. Besides, its thought is that money is the most important factor in the national economy, and the government only needs to control the speed of money issuance. It also holds the view that the stagflation in the western developed capitalist countries is the product of the huge power of government, and that the economic fluctuations after the war for several times are all caused by the government's intervention in the market economy. Friedman opposes to use traditional monetary policy to regulate the amount of money in circulation, and believes that the supply of money should be roughly consistent with the speed of economic development. This theory is known as monetarism. The 
difference between this school and Keynesianism is that in case of simultaneous unemployment and inflation, Keynesianism puts solving unemployment in the first place, while monetarist school puts inflation curb in the first place.

Second, London school, and its representative is Hayek, etc. They are relatively radical liberals, and they oppose state intervention in the economy in any form. They think that the stagnation in the 1970s is because the government monopolizes the issuing power of currency and abuses the power, which eventually damages the market mechanism from playing its role.

Third, it is the supply-side school, a neoliberalism school appearing in the USA in the 1970s, with a representative of Paul Roberts. They believe that the total money supply of the society can be controlled through the gold standard monetary system, and ultimately reduce inflation. They think that tax reduction can increase the rich's savings and investment, while welfare cuts can stimulate the poor's enthusiasm of labor. This school exerts a great influence on the Reagan administration and has achieved certain effect.

The Friedeburg school headed by Erhard advocates that: "implement the third way for the social development of human being, which is neither capitalist (free market economy) nor socialist (centralized planned economy)." In fact, it is the social market economy theory, which intends to combine government intervention with the market mechanism. It emphasizes free competition but no libertarianism. It advocates government intervention, which is different from the socialist economic system. Its essence is free competition under the limited intervention of the state.

The rational expectation school was formed in the late 1950 s and the early 1960s approximately. This theoretical school originally belonged to a part of monetarist school. However, after the 1980s, it had gradually developed into one of the most influential schools of neoliberalism, with representatives of Robert Lucas and so on. In the 1970s, after Keynesianism was beset with a crisis, this school criticized Keynesianism by using rational expectation based on liberal market theory, and believed that its mistake was the violation of the assumption that man was rational in western economics. This school believes that the government can completely withdraw from the market intervention activities. Because they think that the masses of consumers and producers are well-informed forecasters who can make rational expectations of all the government's economic policies. Therefore, all the government intervention will be ineffective.

Basically, these schools disagree with Keynesianism policies, but they are more or less influenced by Keynesianism, and they contain a factor of state intervention. It is also the difference between neoliberalism and the old liberalism. The various schools hold different views on the role of government in the economy. Hayek believes that the government should take measures to ensure the healthy progress of the competition. The state should not be a bystander, but actively establish and maintain an effective competition system. The role of the government is to provide some services which can be beneficial to the society, but cannot be operated by the private on the premise of effective competition. However, the Friedeburg school feels more relaxed for state intervention. They think that the competition is a kind of free competition safeguarded by government. They think that the government should be a referee, so that the full and effective competition can be ensured. The government should provide an environment for market competition, formulating and implementing rules that should be observed in economic activities, instead of direct intervention of private economic activities, even the rational expectation school does not deny the role of the government.

Neoliberalism opposes state intervention in the economy, but at the same time, it hopes the government can intervene to ensure the full and effective competition of the free economy. These scholars hold different views on the role of government in the economy, but they all attach great importance to the state monetary policy.

\section{PRACTICE OF NEOLIBERALISM IN VARIOUS COUNTRIES}

The effect obtained by neoliberalism theory arising from the practice of various countries is the most controversial. After the implementation of neoliberalism, a huge burden occurred in the economy of many countries. From 1980 to 1990 , the result of the implementation of neoliberalism policy in western countries was that: "In 1991, a new round of economic recession occurred. The western countries, including the UK and USA, were generally burdened with heavy debts. The stock of debt of the countries, enterprises and families broke the historical records. The unemployment rate has reached the highest level since WWII with the number of unemployed people of 38 million, which is twice the population of Scandinavia." [2] Only in the privatization movement initiated by Mrs. Thatcher and the disinflation and anti-deficit policies carried out by the Reagan administration, did neoliberalism achieve certain results.

Neoliberalism achieved great success in the UK from the 1970 s to the 1980 s. After the right-wing Conservative Party returned to its power in UK, Prime Minister Mrs. Thatcher began to promote the in-depth reform of the welfare state system. She regarded the monetarism of neoliberalism as the main thought and put forward a systematic economic policy aimed at relaxing state intervention and restoring the vitality of the free economy, and launched a large-scale privatization movement. Her reform ideas and policies are known as 
"Thatcherism", which is similar to the "Reaganism" promoted by Republican President Reagan in the USA, and the two thoughts are collectively referred to as neoliberalism.

Mrs. Thatcher's policies in Britain were effective at that time. Since 1982, the British economy has experienced eight years of sustained growth, which is rare after the war. The domestic labor productivity and economic benefits have been significantly improved, the competitiveness of goods has been enhanced. As a result, the fiscal deficit, has lasted for 18 years, has turned into surplus since 1987. For a time, it seemed that Britain was no longer the "sick man of Europe". In the meantime, the annual inflation rate of the UK dropped from nearly $22 \%$ in the early 1980 s to less than $4 \%$ in the mid-1980s. All these achievements were once regarded as one of the outstanding achievements of Thatcherism.

Of course, what people can't ignore is that some of the achievements made by Thatcher government are at the cost of aggravating social contradictions. During the Thatcher Administration, the severe deflationary policy what Mrs. Margaret carried out directly caused that 2 million people were unemployed, accounting for about $13 \%$ of the total labor force in the UK. In addition, in the implementation of such policies, the old industrial areas in the north of the UK were seriously impacted, while the south was fully developed. Thus, the imbalance of internal economic development in the UK was increasingly obvious. Meanwhile, the reform of the tax system had also caused more serious polarization between the rich and the poor. The tax burden of the rich had been reduced, while the tax burden of the poor had increased. These consequences also made Mrs. Thatcher had certain controversies in the UK. In recent years, the economy in the UK is still affected by inflation, and the domestic economy is growing slowly, which makes people doubt the actual effect of neoliberalism.

The countries greatly influenced by neoliberalism include not only developed capitalist countries, such as the UK and the USA, but also countries and regions, such as Russia and Latin America. The above-mentioned countries intend to develop their own economy and carry out radical reforms with strong characteristics of neoliberalism. Some eastern European countries have achieved good results. For example, Bonan has adopted the "shock therapy" proposed by neoliberalists in the transition, and its economy has made great progress. However, more countries were in a dilemma as a consequence.

In the 1980s, a serious debt crisis and economic crisis broke out in Latin America, and their economy suffered a heavy impact. However, the UK, the USA and other countries had achieved good results through the implementation of neoliberalism. We can see that neoliberalism has a great influence in the world. Many Latin American countries had accepted the reform proposals of neoliberalism, and their momentum of economic reform was very strong, and its deep influence was rare in the history of Latin American countries. The reform carried out achieved certain results at that time. The Latin American countries got rid of the predicament temporarily. And some of them realized the transformation from the closed import substitution mode to the extroverted development mode. The hyperinflation was controlled, and the macroeconomic situation was improved for a time.

However, what can not be ignored is that the results of the reforms carried out by Latin American countries are still too small. And many sequelae are caused by this reform, first, in the process of privatization of stateowned enterprises, the serious loss of state-owned assets makes some industries concentrate on private capital and foreign capital, and the unemployment problem is even more serious; second, the problem of unfair income distribution is becoming more and more prominent, and polarization and impoverishment are very serious. For example, before the reform, there were two billionaires in Mexico, and the number was increased to more than 20 in the late 1990s. At the same time, the number of poor people had not decreased, but increased [3];third, the domestic enterprises are in trouble. After opening up, domestic enterprises have been greatly impacted. And such situation is particularly obvious in Mexico, Argentina and other countries with a high opening degree; fourth, the functions of the state are obviously weakened and social development is seriously neglected; fifth, financial liberalization leads to financial crisis. After the reform, there were financial crises in Latin America. These problems brought great hidden dangers to the economic development of Latin America, however, neoliberalism had not solved them well.

Russia is also an important country that promotes neoliberalism. After the collapse of the former Soviet Union, Russia began to implement "shock therapy". The basic basis of "shock therapy" is "Washington consensus". And its main contents include: market liberalization, privatization of state-owned enterprises and economic stabilization, and full opening of markets to western countries. The "shock therapy" is a classic work of neoliberalism.

After putting "shock therapy" into force, Russia was in an unprecedented economic dilemma during economic transformation. The "shock therapy" caused a huge impact on Russia's economy. The polarization between the rich and the poor in Russia had become increasingly serious, and the economy had declined greatly. In 1989 , GDP of Russia was more than twice that of China, however, after 10 years, it was only one third of that of China. [4] Neoliberalism did not save the Russian economy, instead, it made the Russian economy fall into the abyss, leading to a serious economic and political crisis. Due to the lack of enough attention to the essential 
differences between Russia and the western economic system, the theories and policies of neoliberalism didn't make the Russian economic situation better, but worse. Such complete failure of neoliberalism in Russia speaks volume that some strict preconditions are necessary for the positive operation of free market economy. If it ignores these conditions or implements in an extreme manner, an economic disaster will be caused.

On the whole, the achievements obtained by neoliberalism in the world are not optimistic. In European countries except the UK and the USA, many middle left wing forces have resisted neoliberalism to varying degrees. Most developing countries carrying out neoliberalism are in economic difficulties, especially Argentina and other countries. So, these countries are firmly opposed to neoliberalism. The effect of neoliberalism in the world was uneven, so many countries also began to reflect on neoliberalism. In 1998, the summit of the Americas held in Santiago explicitly replaced the "Washington consensus" with the "Santiago consensus". This act can exactly explain that developing countries have begun to abandon neoliberalism.

\section{ENLIGHTENMENT OF NEOLIBERALISM TO CONTEMPORARY CHINA}

After implementing the reform and opening-up policy, China introduced and absorbed foreign excellent civilization achievements, and draw lessons from foreign advanced management methods and systems as per its own situation. Under the overall background, neoliberalism is naturally introduced into China, and Chinese scholars are also very concerned about neoliberalism, some of them oppose it while others support. From the perspective of the source of neoliberalism and its practice situations in various countries, China should critically absorb it instead of indiscriminately imitating foreign theories. As an economic trend of thought and theory prevailing in the world, neoliberalism is developed based on classical liberalism economic thought. This theory has a history of the development for $200+$ years. Its vitality is so tenacious, we can certainly know that it has its scientific component. It is the common civilization achievement of human development. Therefore, we should treat neoliberalism dialectically and draw lessons from and make use of it critically.

Above all, privatization. In the views of neoliberalism scholars, private ownership is the best system in the world. Only by carrying out private ownership can individual freedom be guaranteed; only when individual freedom is guaranteed can market mechanism work; only under the spontaneous regulation of the market, can the economy automatically achieve equilibrium and achieve optimal performance. However, in the public ownership society, the poor have to bear the heavy pressure of the huge state management institutions, and they are not the owners of public property at all. Therefore, many countries privatize numerous state-owned enterprises after the implementation of neoliberalism. "Throughout the $1980 \mathrm{~s}$, the process of privatization had been accelerating. By the early 1990s, most state-owned enterprises in developing countries had been privatized. Among them, the monopoly enterprises providing basic public services were in the majority, including water, electricity and telecommunications. The unsound stock markets in these countries made the international consortia could easily buy shares in public enterprises. The eastern European countries, which used to have a centrally planned economy, had also repeated this situation. By the mid-1990s, the total amount of privatization in poor countries and eastern European countries was more than USD 58 billion." [6] However, in fact, privatization does not necessarily lead to economic growth. Even some western economists admit that privatization cannot promote economic development by itself. The practices of many developing countries are also examples.

Secondly, marketization. Neoliberalism expands the role of market mechanism indefinitely, opposes the state intervention in the economy, and it thinks that the government intervention in the economy will disturb the ability of self-improvement and self-regulation of the market, and cause a series of social and economic problems. Abandoning government intervention can optimize the allocation of resources, promote fair market competition, and make economic activities more efficient. But the truth is that the developed capitalist countries headed by the USA are crazy about neoliberalism policies carrying out in the third world countries, while they are constantly using government intervention to safeguard the interests of the monopoly bourgeoisie. For example, "after the 911 incident, the aviation industry of the USA was in a depression, and the US government implemented the high subsidy policies. Furthermore, the USA pursued "neoliberalism" economic policy; while using Keynesian theory to engage in deficit finance, expanding demand and increasing armaments. "[5]

The last is deregulation. Neoliberalism holds the views that to ensure the normal operation of the market, it is necessary to implement deregulation in the market economy. For example, the public expenditure of the government on education, medical care, labor protection and other social services. The above-mentioned theoretical guidance directly makes many countries reduce the expenditure on welfare and other aspects, while relaxing the control of the financial industry, which makes ordinary people are more difficult to obtain loans. And people's living standards are directly affected. The deregulation promoted by neoliberalism makes the polarization between the rich and the poor more obvious, and ordinary people are on a sticky wicket for the competition. 


\section{CONCLUSION}

In view of China's situation, we should not forget the suffering of the Soviet Union and eastern European countries. We should be alert to its harm and learn lessons from other developing countries. The economic theories of each period have an intimate connection to the economic situation and realistic conditions at that time. The economic theories will have an important impact on economic development, and neoliberalism theory is no exception. For this reason, while studying and drawing lessons from neoliberalism, we must combine with its historical environment at that time. We can neither indiscriminately imitate nor totally deny it. We should combine it with the actual condition of China and scientifically absorb the reasonable elements of it. The current situation in China is different from the free competition of early capitalism as well as the state monopoly of modern capitalism. In fact, it has a relatively complex and special historical environment and social, economic and natural conditions. Therefore, the economic development of China should have characteristic path and choice. We should establish a socialist market economic system suitable for our own actual condition and a modern enterprise system suitable for our market economy, so that the enterprise can really become the main body of the market; cultivate and perfect the socialist market system, make the market mechanism play a basic role in the allocation of resources; transform government functions, separate government functions from enterprise management, strengthen the economic functions of both state and government, and make them implement the functions of supervision, service, coordination and planning for the macro economy in an effective manner; establish and perfect the social security system as soon as possible, so as to create a stable and harmonious social environment for the stable growth of economy.

The emphasis on state excessive intervention and monetary stability is relatively concentrated among all the proposals of neoliberalism, which is also recognized by many schools. There are two points in the policy proposal of neoliberalism that we should learn from and pay attention to. As for the practice of neoliberalism, Germany has made remarkable achievements. The economic management of Germany has no special secret, which is mainly the combination of government intervention and market economy. As Mr. Erhard from Germany says, "solve the long-standing contradiction between unrestricted freedom and ruthless government regulation, then, we can find a sound middle road between absolute freedom and totalitarianism." We can see that the German government intervention in the economy is different from that of other countries. Germany emphasizes the regulatory intervention in the operation link of the market economy other than adopting expansionary fiscal policies as well as monetary policies to solve the scant demand caused by the disadvantages of the market economy, so as to maintain the sound operation of the market economy. Such management mode really brings a stable growth to German economy for quite a long time. Neoliberalism also attaches great importance to monetary stability, it thinks that: Whether it is in economic depression with serious unemployment, or economic prosperity with full employment, it must maintain the stability of currency and price of commodities. It believes that excessive money will not only lead to inflation, but also make personal wealth shrink. This view has referential value many countries, including China.

\section{REFERENCES}

[1] Friedrich August Hayek: The Road to Serfdom, China Social Sciences Press, 1999 edition.

[2] Qian Wu, Economic Globalization and the Global Expansion of Neoliberalism Ideology, Chinese Cadres Tribune, Issue 1 in 2002.

[3] Research Group of "Neoliberalism Research" of Chinese Academy of Social Sciences, Research on Neoliberalism, Marxist Study, Issue 6 in 2003.

[4] Alan G. Nasser, the tendency to privatize, monthly review, March 2003.

[5] Deqiang Han: Speculations on Anti-economic Globalization, contained in Globalization, Antiglobalization and China Edited by Pang Zhongying, Shanghai People's Publishing House, 2002 Edition.

[6] Bing Ding, Neoliberalism and Economic Globalization - Analysis of the Negative Impact of Economic Globalization, Contemporary Economic Research, Issue 6 in 2002.

[7] Qiqing Li, Neoliberalism in the Context of Globalization, Marxism and Reality, Issue 5 in 2003. 